\title{
腰椎後側方固定術における多椎間固定について
}

\author{
日赤長崎原爆病院整形外科

$\begin{array}{lllllll}\text { 藤 } & \text { 田 } & \text { 雅 } & \text { 章・田 } & \text { 口 } & & \text { 厚 } \\ \text { 麻 } & \text { 生 } & \text { 英 } & \text { 保・山 } & \text { 田 } & \text { 正 } & \text { 幸 } \\ \text { 平 } & \text { 田 } & \text { 重 } & \text { 則 } & & & \end{array}$

\section{Comparison of Single and Multiple posterolateral Lumbar-Spine Fusion}

by

\author{
M. Fujita, A. Taguchi, H. Aso M. Yamada and S. Hirata \\ Division of Orthopaedic Surgery, Japan Red Cross Nagasaki \\ Atomic Bomb Hospital Nagasaki Japan
}

\begin{abstract}
About 200 cases of posterolateral lumbar-spine fusion were performed in our hospital from 1972 to 1979 in which 115 cases were examined during the period of more than three years.

Among these, 83 cases (112 intervertebral spaces) were followed up and compared with single and multiple posterolateral lumbar-spine fusion which were mainly assessed by roentogenographic and clinical results.

The incidence of solid fusion was high, $84.3 \%$ (intervertebral spaces, $88.4 \%$ ).

For one level fusion the incidence was $94.6 \%$ and for multiple levels the incidence showed $63.0 \%$ (intervertebral spaces, $82.1 \%$ ) solid fusions.

For disc lesions we had solid fusion in $93.3 \%$ (intervertebral spaces, $95.0 \%$ ) but for spondylolysis and spondylolisthesis in $75.0 \%$ (intervertebral spaces, $81.0 \%$ ).

In our cases there were no clear correlations between clinical and roentgenographic results.

It is suggested that cross unilateral lumbar-spine fusion is effective in the cases which need multiple spine fusions.
\end{abstract}

\section{はじめに}

腰椎後側方固定術は, 1953 年, Watkins が報告し て以来，骨瘉合が良好なととから注目されるようにな り，本邦でも高岸らをはじめ，多くの優秀な成績が報 告されている.しかし，本法の術後成績を判定するた めに必要な追跡期間や，その多椎間固定の意義につい ては，まだ論議の多いとてろである．われわれは，昭 和 47 年 8 月より 54 年 8 月までに約 200 例に本法を施 行し, 術後 3 年以上経過した例は 115 例に達してい る. 現在までに，そのうち 83 例（112 椎間）を追跡調 査することができた．今回は特に 1 椎間固定 56 例と， 多椎間固定 27 例 (56 椎間) の両群をレ線学的, 臨床
的に比較したので報告する.

\section{I 対象}

83 症例中, 直接検診したもの 44 例，アンケートの みのむの 39 例である. 男性 57 例, 女性 26 例で, 年 令は 16 才から 61 才, 平均 34.3 才で follow up まで の期間は, 3 年から 7 年（平均 4 年 8 力月）となって いる. 疾患は, 椎間板症が 45 例 (60 椎間), 分離症 21 例 (30 椎間), 分離之り症 11 例 (12 椎間), 無分離 之り症 5 例 ( 7 椎間), 脊椎管狭窄症 1 例 ( 3 椎間) となっている。

\section{II 手術術式について}

手術用については, Mac Kay-Frame を用いてい るが，全身麻酔下に腹圧がかからないよう十分調整を 
する．侵入路は，正中背側縦切開を用いる．部位の確 認と椎間板の変性度の判定には, discography を施 行している. 術中の segmental artery の止血が, 出血量减少の大きなポイントになるが，電気メスの使 用や開胸器よりヒントを得た特殊な開創器を用いて術 中操作を容易にするよう工夫している．骨移植には， 1 椎間あたり， $1 \times 4.5 \mathrm{~cm}$ の骨串 2 本と，十分な bone chip を採取する. 下肢症状のある例では，そ の反対側の腸骨より採取している. 術後は, 約 6 週間 ギプス床に臥床させるが，高令者，多椎間固定例など では 1 週間程長く臥床させる. 6 週後よりフレームコ ルセット装着の上, 2 力月間歩行等の回復訓練をし, 以後軟性コルセットにかえ，遅くとも術後 1 年で装具 は除去するようにしている.

III 成績評価について（表 I ）

レ線上の骨癒合の分類は, 表 I の如く，4つに分け
た. 即ち, 1. Complete：骨癒合が鮮明で，不安定 性のないむの，2．Incomplete-I：片側の骨瘉合が 不鮮明だが不安定性のないもの，3． Incomplete-II : 片側の骨癒合が不鮮明で, 不安定性のもるもの,

4. Incomplete-III : 骨癒合むなく, 不安定性の著明 なあのであり，Incomplete-I までを union とし た.

臨床成績評価は, 河野の分類に従い, 優, 良, 可, 不可の 4 つに分け, 満足度む， $\mathrm{E}$ : 非常に満足, $\mathrm{G}$ : まあまあ満足, $\mathrm{F}$ : 術前と変らない, $\mathrm{P}$ : 術前より悪 くなった，の 4 つに分けた.

\section{IV 結果}

（1）疾患別総合成績（表 II）

疾患別の骨癒合率をみると，椎間板症では $93.3 \%$ （椎間別では $95.0 \%$ ） と良好だが，分離症では 66.7 \%(椎間別では $72.7 \%$ ), 分離之り症では $80.0 \%$

$<$ 表 $1>$ 骨㾙合 の 分類と評価

$<$ 骨癒合の分類と評価 $>$

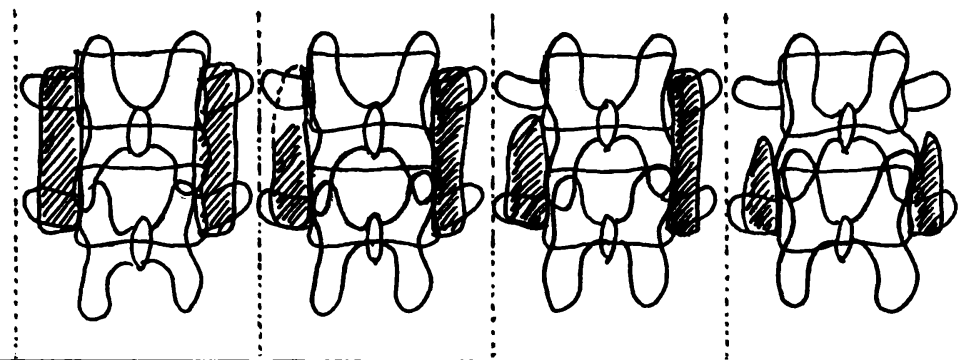

\begin{tabular}{|c|c|c|c|c|}
\hline \multirow{2}{*}{ Type } & \multirow{2}{*}{ Complete } & \multicolumn{3}{|c|}{ Incomplete } \\
\hline & & I & II & III \\
\hline 不安 定 性 & $(-)$ & $(-)$ & $(+)$ & $(H)$ \\
\hline 固定部位 & & & & ion \\
\hline $\mathrm{L} 3 / 4$ & 3 & 0 & 0 & 0 \\
\hline $\mathrm{L} 4 / 5$ & 24 & 2 & 1 & 0 \\
\hline $\mathrm{L} 5 / \mathrm{S} 1$ & 22 & 2 & 2 & 0 \\
\hline $\mathrm{L} 3 / 4+\mathrm{L} 4 / 5$ & 2 & 0 & 2 & 0 \\
\hline $\mathrm{L} 4 / 5+\mathrm{L} 5 / \mathrm{S} 1$ & 14 & 1 & 3 & 3 \\
\hline $\mathrm{L} 3 / 4+\mathrm{L} 4 / 5+\mathrm{L} 5 / \mathrm{S} 1$ & 0 & 0 & 2 & 0 \\
\hline & 65 & 5 & 10 & 3 \\
\hline
\end{tabular}


表 2 疾 患 別 総 合 成 樍

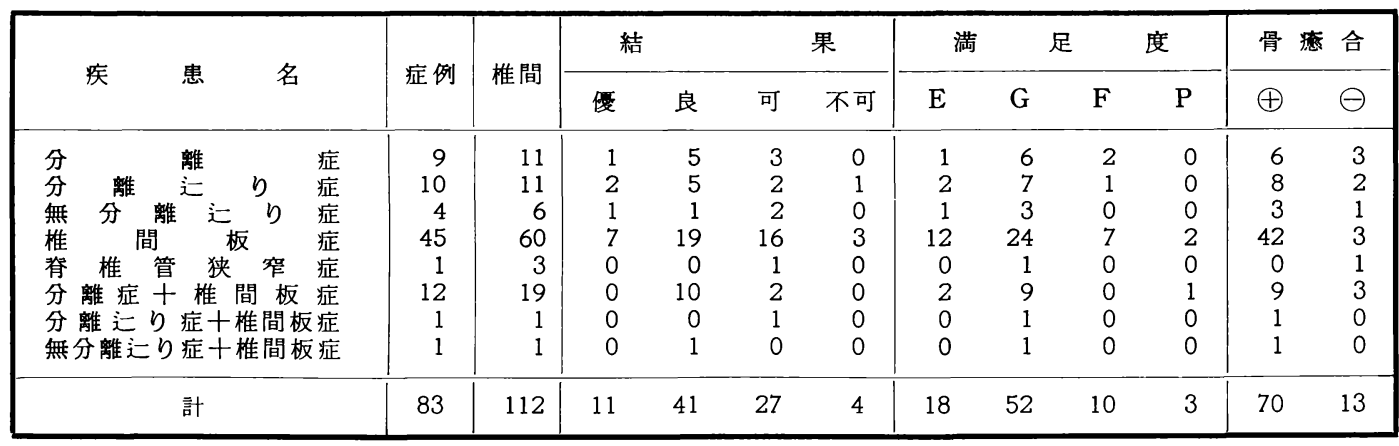

骨瘾合率：疾患，70/83(84.3\%) 椎間, 99/112(88.4\%)

（椎間別では $81.8 \%$ ）と低い值を示していた。 また臨 床的には，椎間板症は，優と良が $57.8 \%, \mathrm{E}$ と $\mathrm{G}$ が $80.0 \%$ ，分離症では，優と良が $76.2 \%, \mathrm{E} と \mathrm{G}$ が $85.7 \%$, 分離过り症では，それぞれ $63.6 \%, 90.9 \%$ となっていた，総合的には，骨癒合率は， $84.3 \%$ (椎間別では $88.4 \%$ ), 臨床的には優と良が $63.9 \%$, EとGが $84.3 \%$ \%ちった.

（2）固定部位（範囲）別総合成績（表 III）

1 椎間固定は, $94.6 \%$, 多椎間固定は $63.0 \%$ （椎 間別では $82.1 \%)$ の骨癒合率を示し， 1 椎間の方が
すぐれていた. また 1 椎間固定の $\mathrm{L}_{4} / 5$ と $\mathrm{L}_{5} / \mathrm{S}_{1}$ で は，それぞれ $96.3 \% ， 92.3 \%$ \%あり，多椎間固定の $\mathrm{L}_{3}$ から $\mathrm{L}_{5}$ と $\mathrm{L}_{4}$ から $\mathrm{S}_{1}$ をみると，それぞれ 50.0 \%, $71.4 \%$ となっていた. 臨床的には，優と良は， 1 椎間で $62.5 \%$, 多椎間で $66.7 \%$, 満足度の $\mathrm{E}$ と は $82.1 \%, 85.2 \%$ とり，わずかに多椎間固定例が すぐれていた.

(3) 自覚症状と他覚症状

自覚症状は, 腰痛, 下肢痛, 殿部痛, 下肢のしび れ, 立位痛, 坐位痛, 腰部倦急感などについて調査し

表 3 部 位 別 総 合 成 績

\begin{tabular}{|c|c|c|c|c|c|c|c|c|c|c|c|c|}
\hline \multirow{2}{*}{ 固 定 部 位 } & \multirow{2}{*}{ 症例 } & \multicolumn{2}{|c|}{ 結 } & \multicolumn{2}{|c|}{ 果 } & \multicolumn{2}{|c|}{ 満 } & \multicolumn{2}{|c|}{ 度 } & \multicolumn{2}{|c|}{ 骨 瘾 合 } & \multirow{2}{*}{ 骨癋合率 } \\
\hline & & 優 & 良 & 可 & 不可 & $\mathrm{E}$ & G & $\mathrm{F}$ & $\mathrm{P}$ & $\oplus$ & $\ominus$ & \\
\hline L $3 / 4$ & 3 & 0 & 2 & 1 & 0 & 1 & 1 & 1 & 0 & 3 & 0 & $\begin{array}{l}3 / 3 \\
(100 \%)\end{array}$ \\
\hline L $4 / 5$ & 27 & 5 & 11 & 10 & 1 & 4 & 19 & 3 & 1 & 26 & 1 & $\begin{array}{r}26 / 27 \\
(96.3 \%)\end{array}$ \\
\hline $\mathrm{L} 5 / \mathrm{S} 1$ & 26 & 3 & 14 & 8 & 1 & 7 & 14 & 4 & 1 & 24 & 2 & $\begin{array}{l}24 / 26 \\
(92.3 \%)\end{array}$ \\
\hline 小 & 56 & 8 & 27 & 19 & 2 & 12 & 34 & 8 & 2 & 53 & 3 & $\begin{array}{r}53 / 56 \\
(94.6 \%)\end{array}$ \\
\hline $\mathrm{L} 3 / 4+\mathrm{L} 4 / 5$ & 4 & 1 & 1 & 1 & 1 & 0 & 2 & 1 & 1 & 2 & 2 & $\begin{array}{l}2 / 4 \\
(50 \%)\end{array}$ \\
\hline $\mathrm{L} 4 / 5+\mathrm{L} 5 / \mathrm{S} 1$ & 21 & 2 & 14 & 4 & 1 & 6 & 13 & 2 & 0 & 15 & 6 & $(71 / 4 \%)$ \\
\hline $\mathrm{L} 3 / 4+\mathrm{L} 4 / 5+\mathrm{L} 5 / \mathrm{S} 1$ & 2 & 6 & 0 & 2 & 0 & 0 & 2 & 0 & 0 & 0 & 2 & $0 / 2$ \\
\hline 小 & 27 & 3 & 15 & 7 & 2 & 6 & 17 & 3 & 1 & 17 & 10 & $\begin{array}{l}17 / 27 \\
(63.0 \%)\end{array}$ \\
\hline 計 & 83 & 11 & 42 & 26 & 4 & 18 & 51 & 11 & 3 & 70 & 13 & $\begin{array}{l}70 / 83 \\
(84.3 \%)\end{array}$ \\
\hline
\end{tabular}

1 椎間：優・良 $35 / 56(62.5 \%), E \cdot G 46 / 56$ (82.1\%)

多”：優・良 $18 / 27(66.7 \%), E \cdot G ~ 23 / 27$ (85.2\%) 
たが，その改善率は，1椎間と多椎間では大きな差は みられなかった。他覚症状では, Lasègue 症候など の根刺激症状の改善は, 約 $80 \%$ \%みられているが, 知覚, 反射, 筋力などの脱落症状の改善はよくない. 1 椎間では，わずかに後者が良い傾向がみられた。

（4）出血量之手術時間

1 椎間単独の固定例では, 出血量 $700 \mathrm{gr}$, 手術 時 間 1 時間 30 分， 2 椎間では, $1120 \mathrm{gr} 2$ 時間 15 分之 なっている．併用手術があれば， 1 椎間では， $850 \mathrm{gr，}$ 2 時間， 2 椎間では $1125 \mathrm{gr} ， 2$ 時間 30 分という平 均値を示していた.

（5） 職場復帰とその期間

各人の腰痛の原因, 仕事の程度などにより左右され るが，大体 7 力月から 10 力月（平均 9.5 ワ月）で職 場復帰をしており， 1 椎間と多椎間には，大きな差は 見られていない，軽作業までを復帰とすると $89.2 \%$, 転職屯含めると $94.0 \%$ 之高率の復帰をみている.

(6) 合併症

われわれの症例では, 感染 2 例, 血腫形成 4 例, 血 栓性静脈炎 1 例の他に, 肝機能障害が 20 例にみられ た. それらの骨瘉合率は $85.0 \%$ であり，うち 6 例に は輸血はなされていない。

\section{考察}

腰椎不安定症状に対する根治的療法として, 後側方 固定術の適応は，大体確立された感があるが，固定範 囲については, 手術前の明確な不安定椎間だけにとど めるのか. 軽度の不安定性がみられる隣接椎間まで固 定するか論議があるところである.

腰椎固定術の終極の目的は, 腰痛, 下肢痛の患者を 如何にして本来の日常生活に復帰させるかである. 術 後何年間 follow をすべきかの定説はなく，極論すれ ば，生存期間中追跡してはじめてての成績の良否が決 められるべきである. 今回は一応, 最低 3 年後の成績 を調查したが, 大体の感触としては, 術後 1 年目以後 は, 特殊な事情 (外傷, 過労等) がない限り, あまり 変化はみられなかった. また脊椎の退行性変性に伴う 新たな腰痛の発症も考えられることより, 術後 3 年目 の成績の判定が罗当と考えている.

本法の骨癒合率が高いととは，最大の利点である が，その理由としては，骨移植床が広く，血行が豊富 なととや，固定部位が motion axis にあるととなど が挙げられている．諸家の報告では，80９0\%台の
成績が報告されているが，われわれの 症例では 84.3 \%（椎間別では $88.4 \%$ ）であった.

1 椎間と多椎間に分けてみると, Hoover らは，は っきりした差はないと述べ, Stauffer らは, 1 椎間で $75 \%$ ， 2 椎間で $83 \%$, Rombold は 1 椎間で $96 \%$, 2 椎間て $67 \%$ という結果を出している. われわれの 症例では, 1 椎間は $94.6 \%$, 多椎間では $63.0 \%$ （椎 間別では $82.1 \%$ ） 1 椎間の方がすぐれていた. ま た田島らは， $\mathrm{L}_{4}$ から $\mathrm{S}_{1}$ の 2 椎間固定での $\mathrm{L}_{\mathbf{4}} / \mathbf{5}$ の骨 癋合が不良之述べているが，われわれの症例であ，2 椎間固定での 骨癒合不良 6 例中 5 例が $\mathrm{L}_{4} / 5$ であっ た. 乙の原因としては， $\mathrm{L}_{5}$ 横突起での移植骨片の接 触面積が少ないとと, 手術時のカーブとギプス床での カーブの変動が $\mathrm{L}_{4} / \mathbf{5}$ で最も生じやすいとと, 採取骨 量の不足などが考えられる。

臨床成績との関係をみると, non-union の症例で 成績不良例が多いことは, 多くの人により強調されて いるが，骨癒合率と臨床成績は必ずしも一致しない。 添谷らは，骨瘉合率 $95 \%$, 優・良 $85 \%$, 増原らは, それぞれ $100 \%, 95 \%$ ，田島らは $90 \%, 89.6 \%$, 永 田らは $96 \% ， 88 \%$ 之骨癒合率より臨床成績の 方がや や劣る傾向がみられる. われわれの症例でも， 84.3 （椎間別では $88.4 \%)$ と $63.9 \%$ \%ちり，他の 報告よ りあ，更に臨床成績が低くなっている.

骨癒合率之臨床成績が一致しない理由は，いろいろ 考えられる. 腰痛という症状が, 多分に心理的, 社会 的要因に左右され易いこと，臨床症状，レ線所見を充 分把握できず，誤った部位を固定したてと，術後新た な障害が発生したことなどが挙げられる。これが多椎 間固定の場合，特に顕著になるととは充分想像され る.

今回の調査で, 多椎間固定の場合, レ線所見は, 手 術手技が複雑になるため，骨癒合率が低下することは 止むを得ない，然るに臨床症状は一椎間固定とあまり 差がないことは, 前述の心理的要因（手術をうけたと (う安心感) や術後の安静, そして不安定症状の発生 部位が一椎間のみであった場合，当然多椎間固定では その範囲に含まれるため, 症状の改善が得られる等の 理由が挙げられる.

本法の最大の短所である出血が多いととについて は, 多椎間固定の場合，特に留意しなければならな い. 細心の注意を払っての止血操作を行なうのは当然 であるが，あまりにあ出血を少なくすることに気をと 
られて，移植骨の母床の作成を疎かにすると，移植骨 の生着率が低くなる恐れがある. 特に椎体後側面の操 作は是非必要であるが，乙の操作が出血を增やす最大 の原因であり，本法成績向上には不可避の要素であ り，手術手技の習熟以外途はない.

以上の如く骨瘉合率，手術侵襲の大きさや多椎固定 後の骨盤や股関節への負荷の点加らも, 多椎間の固定 は慎重を要するが, 重複した分離迄り症, 異なった椎 間の椎間板障害之 分離症の 合併, いわゆる double herniation などに対しては, 多椎間の固定は絶対的 な適応となる。

軽作業者や比較的高令な患者の多椎間固定には, 交 叉性の片側固定など, 種々の工夫あ最近では行なって いる.

\section{参考文 献}

1) Adkins, E. W. O.: Lumbo-sacral Arthrodesis after Laminectomy. J. B. J. S., 37-B: 208-223, 1955.

2) Hoover, N. W.: Methods of Lumbar Fusion. J. B. J. S., 50-A : 194-210, 1968.

3) 岩崎洋明他: 腰椎および腰仙椎後側方固定術, 日整会誌，43：756-，1969。

4) 增原建二他：腰椎後側方固定術の検討. 中部整 災誌, 13: 863-865, 1970.

5）三谷晋一他：腰椎分離・过り症に対する後側方 固定術。臨整外，10：108-111，1975.

6) 永田覚三他：腰部疾患儿対する後側方固定術, 日整会誌，53：345-356, 1979.

7) Rombold, C.: Treatment of Spondylolis thesis by Postero lateral Fusion, Resection of the Pars Interarticularis and Prompt Mobilization of the Patient., J. B. J. S.,
48-A : 1282-1300, 1966.

8) Stauffer, R. N. and Coventry, M. B.: 54 Posterolateral Lumbar-Spine Fusion., J. B. J. S., 54-A : 1195-1204, 1972.

9) Truchly, G. and Thompson, W. A. L.: Posterslateral Fusion of the Lumbosacral Spine., J. B. J. S., 44-A : 505-512, 1962.

10) 高岸直人他: 腰椎横突起固定術の経験, 中部整 災誌, 8: 625-627, 1965.

11）戸祭喜八他：第 5 腰椎分離症に対する我々の手 術法の吟味, 中部整災誌, 13:196-197, 1970.

12)田島直也他：腰椎後側方固定術の成績と適応に ついて. 臨整外, 12:602-608, 1977.

13）田口厚他：椎間板ヘルニア摘出（Love 法）と 後側方固定の併用に上る治療法. 臨整外, 9:931 $-933,1974$.

14) 漆谷英礼他：腰椎分離逐り症に対する後側方固 定術について。臨整外, 9: 340-345, 1974.

15) Watkins, M. R.: Posterolateral Fusion of the Lumbar and Lumbosacral Spine. J. B. J. S., 35-A : 1014-1019, 1953.

16) Wiltse, L. L., et al. : The Paraspinal Sacrospinalis Splitting Approach to the Lumbar Spine. J. B. J. S., 50-A : 919-926, 1968.

啠問鹿巟島大整形 酒句崇

後側方固定にて, 重労働を許可される迄の期間はど のようにしておられますか, 完全な骨癒合が完成する 迄は長期間かかると思いますが.

\section{回答原爆病院 藤田 雅章}

術後 3 力月までは歩行訓練を主体とし, その後, 腰 痛体操を指導し, 重労働の場合は 6 力月以降に就労を 許可しております. 